\title{
Artikel
}

\section{Intensief Systeemgericht Casemanagement in de jeugdreclassering}

\author{
N.U. van Capelleveen en mr. A.M.E. van Delden-Gerretsen*
}

\begin{abstract}
Wanneer een jeugdige te maken krijgt met jeugdreclassering, richt feugdbescherming Regio Amsterdam, verder te noemen Feugdbescherming, zich bij de begeleiding van de jeugdige niet alleen op de jeugdige zelf, maar op het hele gezin. Conform de door Feugdbescherming ontwikkelde methodiek, Intensief Systeemgericht Casemanagement, wordt het hele gezin betrokken. Deze methodiek wordt toegepast ongeacht het kader (het civielrechtelijke, strafrechtelijke of preventieve kader) waarbinnen Feugdbescherming merkt. In tegenstelling tot in het civiele recht, lijkt de focus in de met in het geval van het strafrecht echter vooral te zijn gericht op de individuele jeugdige verdachte of veroordeelde. In dit artikel mordt daarom onderzocht welke mogelijkheden de wet biedt om te merken volgens het Intensief Systeemgericht Casemanagement in het strafrechtelijke kader, tijdens de uitvoering van jeugdreclassering. Ook worden er aanknopingspunten in de doelstellingen van jeugdreclassering gezocht voor deze merkwijze.
\end{abstract}

\section{Inleiding}

Wanneer een jeugdige ${ }^{1}$ verdacht wordt van of veroordeeld is wegens het plegen van een strafbaar feit, kan hij of zij te maken krijgen met jeugdreclassering. Jeugdre-

* N.U. van Capelleveen is masterstudent Jeugdrecht aan de Universiteit Leiden en was onderzoeksstagiaire bij Jeugdbescherming Regio Amsterdam. Mr. A.M.E. van Delden-Gerretsen is jurist bij Jeugdbescherming Regio Amsterdam en docent voor Studiecentrum Rechtspleging (SSR). Dit artikel is geschreven naar aanleiding van een onderzoek bij en in opdracht van Jeugdbescherming Regio Amsterdam.

1. In het onderhavige artikel worden hier jongeren van twaalf tot achttien jaar onder verstaan. classering kan tijdens het strafproces op verschillende momenten worden ingezet, onder meer tijdens de schorsing van de voorlopige hechtenis, bij een voorwaardelijke veroordeling of in het kader van een afdoening door het Openbaar Ministerie. ${ }^{2}$ Wordt jeugdreclassering ingezet, dan houdt een gecertificeerde instelling toezicht op de jeugdige en wordt de jeugdige door de gecertificeerde instelling begeleid. Jeugdbescherming Regio Amsterdam (hierna: Jeugdbescherming) richt zich, als gecertificeerde instelling, bij deze begeleiding niet alleen op de jeugdige, maar op het hele gezin. Conform de door Jeugdbescherming ontwikkelde methodiek, Intensief Systeemgericht Casemanagement, ${ }^{3}$ wordt het hele gezin(systeem) van de jeugdige betrokken. ${ }^{4}$ Per gezin wordt één gezinsmanager aangesteld, die naar alle leden van het gezin kijkt en niet alleen naar de aangemelde jeugdige, angezien zowel factoren op het niveau van de jeugdige als factoren binnen het gezin of een combinatie van deze factoren een rol kunnen spelen bij het ontstaan of blijven voortbestaan van delinquent gedrag. Door te kijken naar alle leden van het gezin kan een goede analyse worden gemaakt van de oorzaken van het criminele gedrag en kunnen gezinsleden daar waar nodig worden gemotiveerd tot gedragsverandering. Hiermee richt het Intensief Systeemgericht Case-

2. Art. 493 lid 1 Wetboek van Strafvordering, $77 z$ lid 3 sub b onder 2 jo. 77aa Wetboek van Strafrecht en $77 \mathrm{f}$ lid 1 sub a Wetboek van Strafrecht. Vrijwillige jeugdreclassering, zoals neergelegd in de Regeling vrijwillige begeleiding jeugdreclassering, wordt in dit artikel buiten beschouwing gelaten.

3. Zie M. Dinkgreve, NS Live Case Series 2017: Youth Protection Amsterdam Region. Every Child Safe Forever, Ottowa: PGI 2017.

4. Naast het gezin wordt ook altijd het bredere systeem van de jeugdige betrokken, zoals familie, vrienden en anderen die van invloed zijn op de ontwikkeling van de jeugdige. Dit artikel richt zich echter met name op het gezin van de jeugdige en daarom zal in het vervolg van 'gezin' worden gesproken. 
management zich op het verkleinen van de kans op terugval en transgenerationele overdracht van gezinsproblematiek en criminaliteit. ${ }^{5}$ Hoewel (Nederlands) onderzoek naar de effectiviteit van Intensief Systeemgericht Casemanagement nog schaars is, wordt er veel van deze methodiek verwacht. De effectiviteit van Functional Family Parole services, de gezinsgerichte methode die de kern vormt van het Intensief Systeemgericht Casemanagement, is in de context van jeugdreclassering in ieder geval in verschillende onderzoeken aangetoond. ${ }^{6}$

Intensief Systeemgericht Casemanagement wordt toegepast ongeacht het kader (het civielrechtelijke, strafrechtelijke of preventieve kader) waarbinnen Jeugdbescherming is betrokken. Desalniettemin lijkt, in tegenstelling tot in het civiele recht, de focus in de wet in het geval van het strafrecht vooral te zijn gericht op de individuele jeugdige verdachte of veroordeelde. De vraag kan daarom worden gesteld welke mogelijkheden de wet biedt om te werken volgens het Intensief Systeemgericht Casemanagement in het strafrechtelijke kader, tijdens de uitvoering van jeugdreclassering. Dit wordt in dit artikel onderzocht aan de hand van de volgende onderzoeksvragen: in hoeverre is het in het wettelijk stelsel van jeugdreclassering geregeld dat Intensief Systeemgericht Casemanagement toegepast kan worden? En indien dit niet is geregeld, in hoeverre bieden de doelstellingen van jeugdreclassering aanknopingspunten om dit te veranderen en hoe kan zo'n verandering eruitzien?

Om antwoord te geven op deze vragen, zal eerst het wettelijk kader worden geschetst rondom de positie van het gezin in het jeugdstrafrecht. Gekeken zal worden wat er wettelijk is geregeld ten aanzien van het betrekken van het gezin en de toepassing van het Intensief Systeemgericht Casemanagement bij de uitvoering van jeugdreclassering (paragraaf 2). Indien deze toepassing niet of slechts in beperkte mate is geregeld, wordt gekeken of de doelstellingen van jeugdreclassering aanknopingspunten bieden om dit te veranderen en het werken volgens het Intensief Systeemgericht Casemanagement wettelijk te verankeren (paragraaf 3 ). In paragraaf 4 wordt daaropvolgend een aantal mogelijkheden naar

5. I. Busschers \& L. Boendermaker (in press), 'Systeemgericht werken bij gezinnen met meervoudige en complexe problematiek: Intensief Systeemgericht Casemanagement', in: J. Knoth-Dickscheit \& E. Knorth (red.), Hulpverlening aan gezinnen met meervoudige en complexe problematiek, Groningen: Rijksuniversiteit Groningen. Zie ook deze bijdrage voor meer informatie over (de achtergrond en de inhoud van) het Intensief Systeemgericht Casemanagement. Voor transgenerationele overdracht van criminaliteit zie ook H. Ferwerda e.a., 'Het Dalton-effect voorkomen. Nut, noodzaak en lessen voor de aanpak van criminele families', Het Tiidschrift voor de Politie 2018.

6. I. Busschers \& L. Boendermaker (in press), 'Systeemgericht werken bij gezinnen met meervoudige en complexe problematiek: Intensief Systeemgericht Casemanagement', in: J. Knoth-Dickscheit \& E. Knorth (red.), Hulpverlening aan gezinnen met meervoudige en complexe problematiek, Groningen: Rijksuniversiteit Groningen, par. 5. Zie voor een samenvatting van de onderzoeken die zijn gedaan naar de effecten van Functional Family Parole services ook; I. Busschers e.a., 'Measuring program fidelity in case management for high risk families. Validation of the Functional Family Parole-Global Rating Measure', Journal of Social Work 2018, onder Review of FFT \& FFP literature. voren gebracht voor een wettelijke verankering, mede aan de hand van buitenlandse voorbeelden. Ten slotte wordt in paragraaf 5 afgesloten met een conclusie. Het voorgaande wordt onderzocht aan de hand van een wetgevings- en literatuuranalyse.

\section{Positie van het gezin en ouders in het wettelijk} systeem

Het wettelijk kader ten aanzien van jeugdreclassering wordt met name gevormd door het Wetboek van Strafrecht $(\mathrm{Sr})$, het Wetboek van Strafvordering $(\mathrm{Sv})$, de Jeugdwet, het Besluit tenuitvoerlegging jeugdstrafrecht 1994 en het Besluit Jeugdwet. Wie deze wet- en regelgeving erop naslaat, ziet dat het woord 'gezin' of hiermee vergelijkbare woorden nauwelijks voorkomen in de voor jeugdreclassering relevante (wets)bepalingen. Slechts in enkele gevallen lijkt er een plaats in de wet te zijn voor het gezin van de jeugdige. Een voorbeeld hiervan is de mogelijkheid tot huisarrest tijdens de voorlopige hechtenis. Als de rechter besluit dat de voorlopige hechtenis bij de jeugdige thuis ten uitvoer wordt gelegd, betekent dit dat het hele gezin wordt betrokken. ${ }^{7}$ Ook in het onderzoek van de Raad voor de Kinderbescherming speelt het gezin van de jeugdige een rol. Gekeken wordt immers naar de persoonlijkheid en de levensomstandigheden van de verdachte. ${ }^{8}$ In het onderzoek wordt zodoende de gezinssituatie van de jeugdige beschreven. ${ }^{9}$ De meest noemenswaardige bepaling waarin het belang van het gezin van de jeugdige tot uitdrukking komt, is ten slotte artikel 2.1 Jeugdwet dat zich volgens de memorie van toelichting ook tot gecertificeerde instellingen richt. ${ }^{10}$ In dit artikel is bepaald dat de uitvoering van jeugdreclassering gericht is op onder meer: (1) het versterken van het opvoedkundige klimaat in gezinnen, (2) het bevorderen van de opvoedvaardigheden van ouders en (3) het bevorderen van de veiligheid van de jeugdige in de opvoedsituatie. Het gezin speelt zodoende in dit artikel een grote rol. 
In tegenstelling tot het beperkt aantal bepalingen waarin het gezin aan bod komt, spelen ouders ${ }^{11}$ in de relevante wet- en regelgeving een grotere rol. Ouders moeten op de hoogte worden gesteld als hun kind wordt opgehouden voor onderzoek. ${ }^{12}$ Ook kunnen zij de jeugdige verdachte, die van zijn vrijheid is beroofd, bezoeken en vrij met hem communiceren. ${ }^{13}$ Daarnaast zijn ouders verplicht ter terechtzitting te verschijnen en kunnen zij kennisnemen van alle schriftelijke mededelingen aan de minderjarige. ${ }^{14}$ Ook wat betreft de raadsman hebben ouders bevoegdheden. Zo kunnen ouders, ongeacht de wens van de jeugdige, bepalen dat de raadsman verhoorbijstand aan de jeugdige verleent en mogen ze in bepaalde gevallen opkomen tegen het optreden van de raadsman. ${ }^{15} \mathrm{Op}$ het gebied van het jeugdsanctierecht moeten ouders van jeugdigen onder de zestien jaar toestemming geven voor een Halt-afdoening en dienen ouders te worden gehoord bij bepaalde beslissingen rondom de PIJmaatregel en de maatregel betreffende het gedrag van de jeugdige. ${ }^{16}$ Ten slotte moeten ouders bij de uiteindelijke uitvoering van jeugdreclassering worden betrokken bij het opstellen van een plan van aanpak. ${ }^{17}$ Bij Jeugdbescherming krijgt dit vorm door middel van het maken van een gezinsplan. Ook moet rekening worden gehouden met de behoeften en persoonskenmerken, de godsdienstige gezindheid, de levensovertuiging en de culturele achtergrond van ouders en wordt jeugdreclasseerders opgedragen niet alleen in contact te treden met de jeugdige, maar ook met diens ouders. ${ }^{18}$

Deze positie van ouders maakt echter nog niet dat, in tegenstelling tot wat artikel 2.1 Jeugdwet doet vermoeden, het wettelijk is geregeld dat ouders en de rest van het gezin daadwerkelijk betrokken kunnen worden bij de uitvoering van jeugdreclassering en zij bijvoorbeeld moeten meewerken aan de hulpverlening die in dit kader wordt geboden. Een wettelijke basis op grond waarvan ouders verplicht zijn mee te werken, ontbreekt. Het jeugdstrafrecht is primair gericht op de jeugdige; alleen de jeugdige heeft zich immers schuldig gemaakt aan het plegen van een strafbaar feit of wordt daarvan verdacht. ${ }^{19}$ Het strafrecht, ook het jeugdstrafrecht, is uiteindelijk een individueel schuldstrafrecht. ${ }^{20} \mathrm{Om}$ deze reden is vanuit de regering in het verleden dan ook afwijzend gereageerd op het idee ouders te betrekken bij

11. De betekenis van 'ouder' verschilt per wettelijke regeling, zie art. 1.1 Jeugdwet en $131 \mathrm{~Sv}$. In het vervolg wordt onder ouders verstaan: ouders die het gezag over de minderjarige uitoefenen en voogden.

12. Art. $488 \mathrm{~b}$ Sv.

13. Art. 490 lid 3 jo. 45 Sv.

14. Art. 496 en 504 Sv.

15. Art. 489 lid 2 Sv en 503 lid 2 Sv.

16. Richtlijn en kader voor strafvordering jeugd en adolescenten, inclusief strafmaten Halt (aanwijzing van het college van procureurs-generaal 2018, 2018R007, Stcrt. 2018, 29497), par. 4.2 en art. 77u Sr.

17. Art. 4.1 .3 lid 2 Jeugdwet.

18. Art. 2.4 lid 3 Jeugdwet en 4.2.3 Besluit Jeugdwet.

19. Y.N. van den Brink, Voorlopige hechtenis in het Nederlandse jeugdstrafrecht. Wet en praktijk in het licht van internationale en Europese kinder- en mensenrechten (diss. Leiden), Deventer: Wolters Kluwer 2018, p. 546

20. G. de Jonge, 'De verantwoordelijkheid van ouders in het Nederlandse jeugdstrafrecht', FJR 1999, afl. 11, p. 230 het bestraffen van jeugdigen. Invoering van strafrechtelijke instrumenten ten aanzien van ouders stuitte op principiële bezwaren, gezien het strafrechtelijke uitgangspunt van de individuele schuld. ${ }^{21}$

Desalniettemin wordt er in de praktijk wel een beroep gedaan op ouders om mee te werken aan de hulpverlening die wordt geboden in het kader van jeugdreclassering. Niet alleen gezinsmanagers van Jeugdbescherming betrekken het gezin hierbij, ook rechters doen soms een appel op de medewerking van ouders. ${ }^{22}$ Zo komt het voor dat een rechter in een vonnis opneemt dat systeemtherapie noodzakelijk is. ${ }^{23}$ Medewerking van ouders is in beide gevallen, zoals hiervoor duidelijk werd, echter geheel vrijwillig. Werken ouders niet mee, dan zijn er geen juridische instrumenten om medewerking af te dwingen en is toepassing van het Intensief Systeemgericht Casemanagement, waarbij het hele gezin wordt betrokken bij de uitoefening van jeugdreclassering, juridisch gezien niet mogelijk. Indien er dan wel zorgen zijn over het gezin, kan dit voor een gezinsmanager aanleiding zijn om de Raad voor de Kinderbescherming te verzoeken een onderzoek te starten naar de eventuele noodzakelijkheid van een civielrechtelijke kinderbeschermingsmaatregel. ${ }^{24}$

Er zijn plannen vorenstaande wettelijke positie van ouders in het jeugdstrafrecht te wijzigen. Met de modernisering van het Wetboek van Strafvordering wordt de rol van ouders uitgebreider geregeld. In het Wetsvoorstel tot vaststelling van Boek 6 van het nieuwe Wetboek van Strafvordering (hierna: het conceptwetsvoorstel) wordt bijvoorbeeld bepaald dat ouders toegang kan worden verleend tot alle denkbare verhoren tijdens het strafproces. ${ }^{25}$ Ook wordt de rol van ouders op de terechtzitting verbreed. Waar ouders in de huidige regeling alleen een vertegenwoordigende of verdedigende rol op de zitting hebben, hebben zij wat betreft de memorie van toelichting bij het conceptwetsvoorstel ook een rol als informatiebron over de jeugdige. Volgens de wetgever is het bij de beoordeling van een zaak relevant om te weten onder welke omstandigheden een jeugdige

21. Kamerstukken II 1997/98, 25600 VI, 10, p. 4 en Kamerstukken II 1999/2000, 27197, 1, p. 11

22. Daarnaast betrekt een aantal justitiële jeugdinrichtingen ouders bij de behandeling van gedetineerde jongeren; C. Vuijst, "Ouders zijn deel van de oplossing'. Justitiële jeugdinrichtingen betrekken familie bij behandeling', ZonMw Mediator 2018, 32, Zonmw.nl/nl/actueel/ mediator/.

23. Zie bijvoorbeeld Rb. Midden-Nederland 21 augustus 2018 , ECLI:NL:RBMNE:2018:3961. Rechters kunnen bij het maken van de beslissing dat systeemtherapie noodzakelijk is, gebruikmaken van de uitkomsten van het LIJ; zie H. Spanjaard \& C. van der Put, 'Landelijk Instrumentarium Jeugdstrafrechtsketen', PROCES 2012, afl. 5, p. 358.

24. Y.N. van den Brink, Voorlopige hechtenis in het Nederlandse jeugdstrafrecht. Wet en praktijk in het licht van internationale en Europese kinder- en mensenrechten (diss. Leiden), Deventer: Wolters Kluwer 2018, p. 546-547

25. Art. 6.1.1.1.5 Vaststellingswet Boek 6 van het nieuwe Wetboek van Strafvordering (bijzondere regelingen) en concept-memorie van toelichting bij Vaststellingswet Boek 6 van het nieuwe Wetboek van Strafvordering (bijzondere regelingen), p. 9-10. Beide zijn te raadplegen via rijksoverheid.nl/onderwerpen/modernisering-wetboek-vanstrafvordering. 
opgroeit; inzicht bij de officier van justitie of de rechter in de sociale omgevingsfactoren van de jeugdige wordt als onontbeerlijk gezien bij het nemen van strafvorderlijke beslissingen betreffende de jeugdige. De officier van justitie en rechters zullen zich, zo geeft de wetgever aan, een beeld willen vormen van de omgeving van de jeugdige, of deze omgeving een veilige is en of deze ondersteunend kan zijn bij het bijsturen van het gedrag van de jeugdige. Dit beeld kan volgens de wetgever ook bij de keuze van de sanctie van belang zijn. Hierbij is het volgens de memorie van toelichting bij het conceptwetsvoorstel niet alleen belangrijk dat inzicht wordt verkregen in de (on)mogelijkheden van ouders om de jeugdige bij de uitvoering van de sanctie te ondersteunen, maar is het ook denkbaar dat ouders bij de tenuitvoerlegging van de sanctie een actieve bijdrage moeten leveren. ${ }^{26}$ Deze rol van ouders komt ondanks de overweging in de memorie van toelichting echter niet terug in het daadwerkelijke conceptwetsvoorstel en kent dus geen wettelijke basis. ${ }^{27}$ Ook na de modernisering van het Wetboek van Strafvordering zal, indien het conceptwetsvoorstel niet wordt gewijzigd, medewerking van ouders dus geheel vrijwillig blijven.

\section{Aanknopingspunten voor Intensief Systeemgericht Casemanagement}

Het wettelijk kader biedt op dit moment geen basis om het gezin te betrekken in de uitvoering van jeugdreclassering indien medewerking niet op vrijwillige basis geschiedt. In die gevallen is het juridisch gezien niet mogelijk om het werken volgens het Intensief Systeemgericht Casemanagement, en het aanvaarden van de hulp die in dat kader wordt geboden, af te dwingen. Wil men hierin verandering brengen, dan dient er een wettelijke basis gecreëerd te worden die deze werkwijze verankert, naast de bestaande mogelijkheid voor de gezinsmanager om de Raad voor de Kinderbescherming te verzoeken onderzoek te doen naar de noodzaak van een civielrechtelijke kinderbeschermingsmaatregel. Door het creëren van deze wettelijke basis zal het niet langer nodig zijn om over te schakelen op het civiele recht indien ouders niet vrijwillig meewerken. Hiermee worden dubbele maatregelen voorkomen, kan worden voortgebouwd op de reeds bestaande werkrelatie tussen de jeugdreclasseerder en het gezin en wordt voorkomen

26. Zie art. 6.1.1.3.3.4 Vaststellingswet Boek 6 van het nieuwe Wetboek van Strafvordering (bijzondere regelingen) en concept-memorie van toelichting bij Vaststellingswet Boek 6 van het nieuwe Wetboek van Strafvordering (bijzondere regelingen), p. 10-11.

27. Zie ook het advies van de Raad voor de Rechtspraak met betrekking tot het conceptwetsvoorstel, waarin is opgenomen dat het wenselijk is dat deze rol van ouders een wettelijke basis krijgt; Raad voor de Rechtspraak, Advies inzake de wetsvoorstellen tot vaststelling van de Boeken 3, 4, 5 en 6 van het Wetboek van Strafvordering (Modernisering Sv), 2018 (online publiek), p. 115. dat de keten dubbel wordt belast. ${ }^{28}$ Daarnaast zijn er ook gevallen mogelijk waarin de civielrechtelijke weg überhaupt niet openstaat. Voordat een kinderbeschermingsmaatregel door de rechter kan worden opgelegd, zal immers duidelijk moeten worden dat de wettelijke gronden voor de desbetreffende maatregel aanwezig zijn. $^{29}$

Daarbij biedt het creëren van een wettelijke verankering van de praktijk, waarin wordt gewerkt volgens het Intensief Systeemgericht Casemanagement, rechtszekerheid en de mogelijkheid tot rechtsbescherming voor de betrokken gezinnen en vindt het steun in de doelen van het jeugdstrafrecht in het algemeen en die van jeugdreclassering in het bijzonder. Karakteriserend voor het jeugdstrafrecht is namelijk dat het een pedagogische grondslag kent: het jeugdstrafrecht dient een pedagogisch perspectief te bieden. Met een strafrechtelijke reactie wordt dan ook in de eerste plaats de herintegratie, heropvoeding en resocialisatie van de jeugdige en het voorkomen van recidive nagestreefd.$^{30}$ Deze pedagogische notie is onder andere te vinden in artikel 40 Internationaal Verdrag inzake de Rechten van het Kind, waarin het belang van herintegratie wordt benadrukt.

Toepassing van het Intensief Systeemgericht Casemanagement draagt bij aan het bereiken van deze doelstellingen. Doordat de werkwijze zich richt op het gezin van de jeugdige en er wordt gesproken met alle gezinsleden, kunnen onderliggende (gezins)patronen en problemen van het delictgedrag beter in kaart worden gebracht. Hierdoor kunnen passende interventies worden ingezet, teneinde de oorzaken van het delictgedrag weg te nemen en hiermee onveiligheid en recidive te voorkomen. Deze interventies richten zich zo nodig op het hele gezin, aangezien het gezinsdomein van belang is voor het bestaan van bepaalde risicofactoren voor delinquent gedrag. ${ }^{31}$ Ouders worden met andere woorden een deel van de oplossing gemaakt in plaats van dat ze een deel van het probleem blijven. ${ }^{32}$ Dit is effectief gebleken: meta-evaluaties laten zien dat succesvolle interventies zich niet alleen richten tot de jeugdige, maar zich uitstrekken tot ouders en de verdere omgeving. ${ }^{33}$ Zoals uit de inleiding bleek is ook de effectiviteit van Functional Family Parole services, de gezinsgerichte kern van het Intensief Systeemgericht Casemanagement, in verschillende onderzoeken aangetoond. De

28. Zo moet de Raad voor de Kinderbescherming in het huidige systeem naast een onderzoek in het kader van de strafprocedure ook een beschermingsonderzoek uitvoeren als wordt overgeschakeld op het civiele recht en zal de kinderrechter zowel een beslissing moeten nemen in de strafzaak als ten aanzien van het verzoek tot het treffen van een kinderbeschermingsmaatregel.

29. Zie art. 1:255 lid 1 en 1:266 lid 1 Burgerlijk Wetboek (BW).

30. M. Blaak e.a., Handboek Internationaal Jeugdrecht, Leiden: Defence for Children 2012, p. 831

31. Zie J. Reef, 'Risicofactoren voor delinquent gedrag bij jongeren: een overzicht', Strafblad 2014, afl. 1, p. 12-15. Dit blijkt ook uit het LIJ.

32. G. de Jonge, 'Het jeugdstrafrecht kan meer van de ouders vergen', Christen Democratische Verkenningen 1999, afl. 7-8-9, p. 164.

33. I. Weijers, De pedagogische uitdaging van het jeugdstrafrecht, Amsterdam: Uitgeverij SWP 2005, p. 21; zie bijvoorbeeld J. McCord, C. Spatz Widom \& N.A. Crowell (red.), Juvenile Crime, Juvenile Justice, Washington: National Acadamy Press 2001. 
vraag waarom en hoe jeugdreclassering door toepassing van Intensief Systeemgericht Casemanagement effectiever is op kindveiligheid, waaronder het verminderen van recidive, is op dit moment onderwerp van een onderzoek dat wordt uitgevoerd binnen Jeugdbescherming. De uitkomsten van dit onderzoek worden in de loop van 2019 verwacht. Wil men met interventies enig effect bereiken, dan kan men niet om ouders heen, ${ }^{34}$ zeker niet nu bij jeugdigen aan de tenuitvoerlegging van een strafrechtelijke beslissing mede een pedagogische functie wordt toegeschreven. ${ }^{35}$ Zoals ook uit paragraaf 2 bleek, maakt de praktijk - in tegenstelling tot wat er in het wettelijk stelsel van jeugdreclassering is geregeld - wel al gebruik van deze wetenschappelijke inzichten dat de omgeving van grote invloed is op het gedrag van de jeugdige.

Het wettelijk vastleggen van de mogelijkheid tot het betrekken van het gezin bij de uitvoering van jeugdreclassering vindt ook steun in de specifieke doelstellingen van jeugdreclassering, zoals geformuleerd in de Jeugdwet en uiteengezet in paragraaf 2 . Het gezin speelt in deze doelstellingen een grote rol: de inzet van gecertificeerde instellingen moet bij de uitvoering van jeugdreclassering volgens de wetgever zijn gericht op het versterken van een gunstig opvoedklimaat in gezinnen en op het bevorderen van de opvoedingskwaliteiten van ouders, zodat jeugdigen gezond en veilig kunnen opgroeien. ${ }^{36}$ Als ouders tijdig worden bijgestaan, kan erger worden voorkomen en kan worden tegengegaan dat jeugdigen later in zware (zorg)trajecten terechtkomen. ${ }^{37}$ Wordt het hele gezin bij jeugdreclassering betrokken, dan geldt dit bovendien niet alleen voor de jeugdige in kwestie, maar ook voor diens broertje(s) of zusje(s) en wordt getracht de kans op transgenerationele overdracht van gezinsproblematiek en criminaliteit te verkleinen. ${ }^{38} \mathrm{Bij}$ de uitvoering van jeugdreclassering moeten ouders volgens de wetgever dan ook tools in handen krijgen, waardoor zij om kunnen gaan met de opgroeiproblemen van hun kinderen. ${ }^{39}$ Jeugdigen en ouders moeten uiteindelijk op eigen kracht verder kunnen en ouders moeten de verantwoordelijkheid voor de opvoeding van de jeugdige weer kunnen dragen. ${ }^{40}$ Ouders beschikken immers over de eerste verantwoordelijkheid voor de verzorging en opvoeding van hun

34. I. Weijers, De pedagogische uitdaging van het jeugdstrafrecht, Amsterdam: Uitgeverij SWP 2005, p. 21.

35. G. de Jonge, 'De verantwoordelijkheid van ouders in het Nederlandse jeugdstrafrecht', FJR 1999, afl. 11, p. 228

36. Art. 2.1 Jeugdwet onder b, c en e en Kamerstukken I/ 2012/13, 33684, 3, p. 128-129 (MvT).

37. Art. 2.1 Jeugdwet onder a en Kamerstukken // 2012/13, 33684, 3, p. 128 (MvT).

38. Er is immers steeds meer oog voor het voorkomen dat broertjes en zusjes ook met politie in aanraking komen. Zie bijvoorbeeld het Preventief Interventie Team (PIT) dat zich in Amsterdam richt op broertjes en zusjes van Top 1000 personen; https://www.amsterdam.nl/bestuurorganisatie/organisatie/sociaal/onderwijs-jeugd-zorg/zorg-jeugd/ preventief/.

39. Kamerstukken // 2012/13, 33684, 3, p. 129 (MvT).

40. Art. 2.1 sub d en c Jeugdwet en Kamerstukken I/ 2012/13, 33684, 3, p. 129 (MvT). kind. ${ }^{41}$ Wil men aan vorenstaande uitgangspunten voldoen, dan is vereist dat jeugdreclassering zich richt op het hele gezin en pleit dit voor een wettelijke mogelijkheid tot toepassing van het Intensief Systeemgericht Casemanagement. De ouderlijke verantwoordelijkheid kan dan een basis vormen om ouders aan te spreken. ${ }^{42}$ Ouders hebben namelijk niet alleen het recht om hun kind te verzorgen en op te voeden, maar ook de plicht. Onder deze plicht wordt volgens de wet mede verstaan 'de zorg en de verantwoordelijkheid voor het geestelijk en lichamelijk welzijn en de veiligheid van het kind alsmede het bevorderen van de ontwikkeling van zijn persoonlijkheid'. ${ }^{43}$ De omstandigheid dat de jeugdige met het strafrecht in aanraking komt, heeft gevolgen voor zijn welzijn, veiligheid en ontwikkeling. Het strafvorderlijk optreden tegen de jeugdige raakt derhalve ook de ouders. $^{44}$

\section{Mogelijke benaderingen}

In tegenstelling tot in Nederland zijn er in het buitenland meer wettelijke regelingen voorhanden die het mogelijk maken om in het strafrechtelijk kader het gezin te betrekken. Deze mogelijkheden worden in het navolgende besproken ter illustratie en mogelijk inspiratie. Dit gebeurt aan de hand van de 'drie modellen voor het strafrechtelijk activeren van ouderlijke verantwoordelijkheid' zoals opgesteld door Gerard de Jonge. Volgens De Jonge concentreert het jeugdstrafrecht zich te zeer op de jeugdige als individu en houdt het te weinig rekening met diens familiale context. Daarom heeft hij drie modellen ontwikkeld voor het aanspreken van ouders in het kader van strafrechtelijke interventies. ${ }^{45}$ Deze modellen lenen zich voor het onderwerp van het onderhavige artikel, met uitzondering van het eerste model: een punitief model. Dit meest vergaande model houdt in de kern in dat ouders strafbaar zijn als hun kind strafbare feiten pleegt. ${ }^{46}$ Nog los van de op het karakter van het strafrecht gestoelde principiële bezwaren die deze constructie kan oproepen (kwesties rond schuld en verwijtbaarheid) en mogelijke criminologische en pedagogische bedenkingen, lijkt dit model niet geschikt voor het mogelijk maken van Intensief Systeemgericht Casemanagement in de jeugdreclassering. Een strafrechtelijke veroordeling van ouders vormt per slot van rekening nog geen basis om hen bij jeugdreclassering te betrekken indien dit niet op vrijwillige basis lukt.

41. Art. 1:247 lid 1 BW en 18 Internationaal Verdrag inzake de Rechten van het Kind.

42. A. Hakkert, Ouders en reacties op jeugdcriminaliteit, Den Haag: Sdu 1999 , p. 88.

43. Art. 1:247 lid 1 en 2 BW.

44. Concept-memorie van toelichting bij Vaststellingswet Boek 6 van het nieuwe Wetboek van Strafvordering (bijzondere regelingen), p. 10.

45. G. de Jonge, 'De verantwoordelijkheid van ouders in het Nederlandse jeugdstrafrecht', FJR 1999, afl. 11, p. 229

46. Zie G. de Jonge, 'De verantwoordelijkheid van ouders in het Nederlandse jeugdstrafrecht', FJR 1999, afl. 11, p. 229-230. 
Het tweede model dat De Jonge onderscheidt, een dwangmodel, is daarentegen beter toepasbaar. Dit model wordt gekenmerkt door de mogelijkheid voor de rechter om ouders te binden aan opvoedingsbevelen en -aanwijzingen, zoals dat bijvoorbeeld in Engeland, sommige staten van de Verenigde Staten en Zwitserland mogelijk is. ${ }^{47}$ In Engeland kan de rechter door middel van 'parenting orders' ouders verplichten bepaalde in deze order opgenomen voorschriften na te leven, waardoor ouders gedwongen worden controle uit te oefenen op het gedrag van hun kind. ${ }^{48}$ Bepaald kan bijvoorbeeld zijn dat ouders moeten zorgen dat hun kind op tijd thuis is of dat zij de jeugdige tussen school en huis begeleiden. ${ }^{49}$ In de parenting order kan ook worden opgenomen dat ouders een advies- of begeleidingsprogramma moeten bijwonen. ${ }^{50}$ Kenmerkend voor de Engelse benadering is dat ouders strafrechtelijk kunnen worden vervolgd indien ze de verplichtingen uit de parenting order niet (voldoende) nakomen. Door deze constructie kunnen ouders alsnog strafrechtelijk ter verantwoording worden geroepen naar aanleiding van delinquent gedrag van hun kind, zij het indirect. ${ }^{51}$ Ook in de Amerikaanse staat Indiana kan de rechter, onder meer op verzoek van een reclasseringsmedewerker, bepaalde inspanningen van ouders verlangen. De rechter kan bevelen dat ouders meewerken aan de behandeling van hun kind en dat zij hierbij professionele hulp aanvaarden. ${ }^{52}$ Ook de wetgeving van Colorado kent soortgelijke mogelijkheden. In de wet aldaar wordt zelfs expliciet erkend dat gezinnen een belangrijke rol spelen in de oorzaak en aanpak van jeugddelinquentie en dat ouders daarom mee dienen te werken aan de behandelplannen van hun kind. ${ }^{53}$ Ten slotte hanteert Zwitserland een voorbeeld van een dwangmodel. Ook daar bestaat de mogelijkheid ouders instructies te geven. ${ }^{54}$ Blijken deze onvoldoende, dan kan een geschikt persoon worden aangewezen die ouders in hun opvoedingstaak ondersteunt en zijn bepaalde beperkingen van het ouderlijk gezag mogelijk. ${ }^{55}$ Een dwangmodel biedt zodoende verschillende mogelijkheden om het gezin in het strafrechtelijk kader te betrekken. Het werken volgens het Intensief Systeemgericht Casemanagement, en de hulpverlening die daarbij nodig wordt geacht om het delictgedrag van de jeugdige te verminderen, kan zo worden afgedwongen, ook indien dit niet op vrijwillige basis lukt.

47. G. de Jonge, 'De verantwoordelijkheid van ouders in het Nederlandse jeugdstrafrecht', FJR 1999, afl. 11, p. 230

48. Sectie 8 Crime and Disorder Act 1998 onder 4(a).

49. I. Weijers, 'De rol van de ouders in het jeugdstrafrecht', NJB 2009, afl. 10, onder Aansprakelijkheid ouders.

50. Sectie 8 Crime and Disorder Act 1998 onder 4(b).

51. I. Weijers, 'De rol van de ouders in het jeugdstrafrecht', NJB 2009, afl. 10, onder Aansprakelijkheid ouders.

52. Indiana Code 2018 31-37-15 en 31-37-19-24.

53. Colorado Revised Statutes 19-2-113.

54. Art. 12 Bundesgesetz über das Jugendstrafrecht en U. Weidkuhn, Jugendstrafrecht und Kinderrechte. Betrachtung des Schweizerischen Jugendstrafrechts im Lichte der Internationalen Rechte des Kindes und im Vergleich zu Südafrika (diss. Freiburg), Zürich: Schulthess Juristische Medien AG 2009, p. 96.

55. Art. 13 Bundesgesetz über das Jugendstrafrecht.
Het laatste model dat De Jonge onderscheidt, is een coöperatief model. Binnen een coöperatief model draait het om het belonen van opvoedingsinspanningen. Essentieel voor dit model is dat ouders een substantiële positie in het strafproces verkrijgen en dat zij in alle stadia van de procedure worden gehoord. Wat uiteindelijk op de dagvaarding komt te staan, mag geen verrassing voor hen zijn. Op deze manier kan het gesprek met ouders worden aangegaan en kan hun mogelijke rol bij de strafuitvoering in volle omvang aan de orde te komen. Hiertoe stelt De Jonge voor het strafproces in twee fasen op te delen. $\mathrm{Na}$ de juridische fase waarin onder meer wordt gekeken of het tenlastegelegde door de verdachte is begaan, volgt een tweede fase. In deze fase vindt een rondetafelgesprek plaats en wordt besproken welke sanctie aan de jeugdige moet worden opgelegd en welke rol ouders bij de tenuitvoerlegging hiervan, onder begeleiding van de jeugdreclasseringsmedewerker, kunnen en willen vervullen. Houden ouders zich aan deze in het vonnis opgenomen rol, dan stelt De Jonge voor dit te belonen door een deel van de sanctie van de jeugdige niet ten uitvoer te leggen. ${ }^{56}$ In een coöperatief model worden ouders derhalve het meest structureel betrokken bij het strafproces en de uiteindelijke sanctie. Houden ouders zich echter niet aan hun rol bij de tenuitvoerlegging van het vonnis of werken ze helemaal niet mee aan de totstandkoming hiervan, dan biedt het coöperatieve model zoals voorgesteld door De Jonge geen mogelijkheid om betrokkenheid alsnog te bewerkstellingen. In plaats daarvan ondervindt de jeugdige een bijkomend nadeel indien zijn ouders niet meewerken: zijn straf wordt, in tegenstelling tot de straf van kinderen van welwillende ouders, volledig ten uitvoer gelegd.

\section{Conclusie}

Aangezien factoren binnen het gezin een rol spelen bij het ontstaan of blijven voortbestaan van delinquent gedrag en het hele gezin nodig is voor het maken van een goede analyse van de oorzaken van dit gedrag en voor verandering, is in dit artikel onderzocht in hoeverre het in het wettelijk stelsel van jeugdreclassering mogelijk is te werken volgens het Intensief Systeemgericht Casemanagement, de werkwijze van Jeugdbescherming waarbij er naar alle leden van het gezin wordt gekeken in plaats van alleen naar de bij de gecertificeerde instelling aangemelde jeugdige. Hoewel de wet een summiere positie toekent aan het gezin van de jeugdige en een uitgebreidere rol aan ouders, is het, anders dan op vrijwillige basis, op dit moment wettelijk gezien niet geregeld dat het gezin bij de uitvoering van jeugdreclassering wordt betrokken. Daarom is gekeken of de doelstellingen van jeugdreclassering aanknopingspunten bie-

G. de Jonge, 'De verantwoordelijkheid van ouders in het Nederlandse jeugdstrafrecht', FJR 1999, afl. 11, p. 231-232 en G. de Jonge, 'Het jeugdstrafrecht kan meer van de ouders vergen', Christen Democratische Verkenningen 1999, afl. 7-8-9, p. 160-163. 
den om dit te veranderen en hoe zo'n verandering er eventueel uit kan zien.

Doordat het Intensief Systeemgericht Casemanagement zicht richt op het wegnemen van de oorzaken van delictgedrag, wordt bijgedragen aan de heropvoeding en herintegratie van de jeugdige in de maatschappij. Toepassing van het Intensief Systeemgericht Casemanagement beantwoordt daarmee aan de pedagogische grondslag van het jeugdstrafrecht. Bovendien kan het betrekken van het gezin, door middel van het verbeteren van het opvoedkundig klimaat en het bieden van hulp, ook gericht op de eigen problematiek van ouders, eraan bijdragen dat wordt voorkomen dat later zwaardere hulpverlening moet worden ingezet, al dan niet gedwongen. Dit geldt niet alleen voor de jeugdige verdachte of dader, maar voor alle jeugdigen in het gezin. Zodoende draagt het werken volgens het Intensief Systeemgericht Casemanagement bij aan het bereiken van de doelen van jeugdreclassering zoals geformuleerd in de Jeugdwet en aan het voorkomen van nieuwe delicten.

Van de modellen zoals geschetst in paragraaf 4 lijkt een dwangmodel het meest geschikt om het wettelijk mogelijk te maken gezinsgericht te werken in de jeugdreclassering. Ook een coöperatief model biedt echter veel voordelen. Een belangrijk onderdeel van het Intensief Systeemgericht Casemanagement wordt namelijk gevormd door het motiveren van het gezin, zodat iedereen zelfstandig en uiteindelijk uit eigen beweging meewerkt. Van ouders kan immers meer worden verwacht indien zij gemotiveerd zijn, dan wanneer zij iets opgelegd krijgen. Daarom kan worden gedacht aan een combinatie van een dwangmodel en een coöperatief model waarin in eerste instantie zo veel mogelijk naar de eigen motivatie van ouders wordt gezocht. Van belang is dan dat ouders van meet af aan worden geinformeerd en dat zij structureel worden betrokken bij de oplossing van de problemen die door het strafbare gedrag van hun kind zijn veroorzaakt. ${ }^{57}$ In dit verband zijn de plannen om de positie van ouders in het strafproces uit te breiden, zoals neergelegd in het Wetsvoorstel tot vaststelling van Boek 6 van het nieuwe Wetboek van Strafvordering, aan te moedigen. Indien ouders echter ondanks hun rol in het strafproces en de inspanningen van de gezinsmanager niet kunnen worden gemotiveerd, dan is het denkbaar dat zij op hun ouderlijke verantwoordelijkheid worden aangesproken en biedt een dwangmodel uitkomst om het werken volgens het Intensief Systeemgericht Casemanagement alsnog mogelijk te maken. Hoewel de wetgever in de memorie van toelichting bij eerdergenoemd conceptwetsvoorstel aangeeft dat het denkbaar is dat ouders bij de tenuitvoerlegging van de strafrechtelijk beslissing een actieve bijdrage zullen moeten leveren, voorziet de wetgever vooralsnog niet in een wettelijke basis van deze rol. Door middel van deze bijdrage hoopt Jeugdbescherming dat deze wettelijk basis alsnog wordt gecreëerd en dat de wetgever wordt aangespoord om, in het gehele wettelijke stelsel van jeugdreclassering, de toepassing van het Intensief Systeemgericht Casemanagement wettelijk te verankeren. 